\title{
Viewing Diasporas from the Pacific: \\ What Pacific Ethnographies Offer Pacific \\ Diaspora Studies
}

Ilana Gershon

$\mathrm{W}_{\mathrm{he}}$ hen many analysts of transnational movements turn toward families, they ask how diaspora disrupts them. They are concerned with the ways in which travel and distance forces people to reconstitute their families in new configurations in response to the exigencies of migrating. For example, Alejandro Portes and Rubén Rumbaut have written evocatively about how second-generation immigrants struggle with assimilation as they respond to parental and societal demands, with parents standing for the homeland culture (200I). Others, such as Kye-Young Park (I997) and Caroline Brettell (2003), have discussed the dynamics underlying changes in gender relations among diasporic migrants. The authors emphasize ruptures and reconstructions, often describing diasporas as obstacles to be overcome. This focus renders diasporas as dislocations that wound, and families as units of recovery that heal to varying degrees. However, ethnographers of Pacific diasporas offer a different perspective on Pacific Rim diasporas.

In the Pacific, it is families and their transnational connections that sustain diasporas, making them both durable and visible. Without families and familial knowledge transmission, how would diasporas remain compelling concepts for interpreting differences as cultural or ethnic? By pointing out that families are the culturally specific, integral units that constitute diasporas, I am building on Epeli Hau'ofa's insight that to understand the Pacific, one is better served by attending to people's daily experiences of interconnected webs of exchanges and kinship than by focusing on the disconnections and isolations integral to a Western colonial perspective (1994). Ethnographers of the Pacific have long known that the Pacific is not just a sea of islands, but also a sea of families. ${ }^{1}$ Diasporas only exist

The Contemporary Pacific, Volume I9, Number 2, 474-502

(C) 2007 by University of Hawai'i Press 
because of the culturally specific ways through which families circulate knowledge and resources. Yet to say that families make diasporas tangible is not enough. Families and diasporas are intertwined, connected to such a degree that diasporas cannot exist across generations without families sustaining them. The question posed in this article is: In what ways do transnational families function so as to endow diasporas with longevity?

This question takes a very specific perspective on Pacific Island diasporas, one that is shaped by the culturally specific structures of families, rather than by "ethnoscapes" or nations. ${ }^{2}$ To think about diasporas through families is to think through a specific level of scale; it entails thinking about national limits and transnational movements from the perspective of a much smaller and differently bounded network. In describing families as networks, I am relying on actor-network theorists' rendition of what a network is - which, as Marilyn Strathern pointed out, is "an old term newly inflected" (I996, 520). John Law has further suggested that "the network is itself a form - or perhaps a family of forms - of spatiality: that it imposes strong restrictions on the conditions of topological possibility. And that, accordingly, it tends to limit and homogenize the character of links, the character of invariant connection, the character of possible relations, and so the character of possible entities" (I999, 7).

For Law, as for other actor-network theorists, networks are the product of constant labor on the part of all who participate-labor that shapes how people and objects interact. This labor involves the effort of constantly excluding other possible ways that particular relationships might be performed. To see families as culturally specific networks is to understand families as forging through daily practices the principles that determine who is considered a family member, and what such relationships entail in terms of how knowledge and resources are circulated. Thus, for example, in some family networks in-laws are considered family members, while in others they are not. At stake are both the nature of families as networks, and how such networks shape analytical perspectives.

For my discussion of Pacific ethnographies, one of the unwelcome consequences of a focus on familial networks is that many salient issues in Pacific diaspora studies in general can easily be relegated to the background. These issues include the legacies of colonialism, economic marginalization, ethnic inequalities, and sovereignty struggles. ${ }^{3}$ But simply because these issues are downplayed does not mean they are absent; indeed, it is in the nature of networks to suppress alternative connections in specific contexts, only to have the alternatives become visible elsewhere. 
In turning to ethnographies of Pacific diasporas as a fruitful site for understanding the ways in which families form diasporas, I am taking advantage of what Arjun Appadurai might term a "gatekeeping concept" in anthropological studies of the Pacific (1986). Appadurai argued that certain regions seem to offer archetypically apt ethnographic examples for unfolding anthropological theory. For instance, when one wants to think about hierarchy, one turns to India; when one wants to think about structured mythological discourse, studies of tropical South America can provide special insights (Appadurai I986, 357). In this fashion anthropological theory becomes localized. However, several scholars have argued that localizing theory presents a hazard, in that these anthropologically compelling, ethnographically grounded social configurations will limit the terms of anthropological debate, both regionally and theoretically (see Appadurai 1986; Fardon I990; Strathern I988a). The risk of relying on ethnographic specificity is that specificity may shape the interpretations of other instances. Such gatekeeping concepts are thus a double-edged sword. In this article, I take as a positive the long-standing scholarly focus on how Pacific families constitute themselves through more or less predictable exchanges of resources and knowledge. This focus has shaped scholars' gaze (I believe for the better) as they begin to discuss emergent Pacific diasporas. Partially as a consequence of a historical commitment to studying exchange in the Pacific, ethnographers of Pacific diasporas have much to say about the ways in which families fashion diasporas, although I want to reiterate Appadurai's caution that these findings have specifically Pacific, even Western Polynesian, valences. ${ }^{4}$

Scholarly traditions are not the only reasons scholars have found Pacific families and their structures so helpful for thinking about diasporas. Pacific nations are often considered MIRAB economies, with remittances often providing over 50 percent of the nations' gross domestic product. ${ }^{5}$ The statistics on remittances are the national traces of how families exchange. ${ }^{6}$ Kerry James has recently argued for a more complex understanding of the ways in which exchanged objects can make family connections concrete and compelling (I997). James and others have criticized the scholarly perspective on remittances in the Pacific that considers the flow of money and goods a one-way street (see, eg, Connell and Brown I995). James turned to the exchange of locally valued objects to reveal the ways these exchanges move back and forth across the Pacific. ${ }^{7}$ She discussed the importance of mats and barkcloth for Tongans in exchanges, regardless of locale (see Addo 2004 for a more detailed account). Indeed, James pointed 
out that just as Tongan mats and barkcloth are valued in ways that undercut a narrowly defined capitalist gaze, so too is money. The remittances that migrants send back to their home islands are immediately funneled into the complex exchange networks that ensure a constant circulation of food, textiles, and money through Tongan family networks. (Other ethnographers have made similar points about Cook Islanders and Samoans; see Alexeyeff 2004; Macpherson I992, I994; Yamamoto I997.) Kerry James, Helen (Morton) Lee, and others have discussed how the symbolic value of objects made in Tonga or other Pacific Islands fuels complex exchange networks that can be sustained across generations. In order to understand the ways remittances occur, one must understand the ways in which families circulate money (see Lee 2004b; Brown 1995; Goss and Lindquist 2000; Vete I995). Remittances have become a meeting point between studies of developing countries and anthropological theories of exchange. Ethnographers of Pacific diaspora thus have focused on families as exchange networks because of this fortuitous confluence between theoretical traditions and practical concerns.

Thinking of families as networks is a familiar project for ethnographers of diasporas in general as well as for anthropologists of the Pacific. In the I960s, scholars began to find networks useful analytical constructs as they tried to understand the relationship between migrating families and cultural commitments. Initially, scholars of urban African migration such as British social anthropologists Arnold Leonard Epstein (1969), Philip Mayer (I961, I962), and Berthold A Pauw (1963) turned to networks as analytical categories to understand a question that will be familiar to many readers: Why are the migrants encountered by ethnographers not assimilating fully to their new urban settings? The dilemma is a puzzling one for a scholar who insists on viewing migrants as individual opportunity seekers trying to succeed in new social contexts. Seeing families as a collection of individuals compels analysts to discern the ties that bind, be they love, obligation, or some other motivation. From this perspective, belonging to a family is far more fragile - a way of being that each member must actively choose at some level. This fragility ensures that diasporas pose significant obstacles to maintaining families; indeed, diasporas would vanish quickly if the selves being circulated were perpetually making choices as though they were self-interested actors.

But as these scholars of urban African migration determined, it is misleading to view migrants as individual decision makers rather than as nodes in a network. By reconceptualizing the migrants as members of 
family networks, scholars opened the door to seeing the people they studied as more than simply individuals seeking other lives when leaving one country for another. Migrants were instead seen as part of larger diasporas in which knowledge and resources circulated through people in multiple directions - to their local friends and relatives as well as to their families back home. From this perspective, assimilation becomes a differently charged question; no longer is it a goal that all migrants should achieve as quickly as possible for their own self-interest. Assimilation becomes refigured as new networks into which actors can potentially enter, ${ }^{8}$ and old networks that must be cut (for a discussion of cutting networks, see Strathern I996). In this sense, even the term "assimilation" becomes misleading as a way to think about diasporic experiences. Instead, the question of assimilation becomes: Why must some networks be cut, and for how long? ${ }^{9}$ Viewing families as networks enables scholars to understand how communities might stretch their boundaries across larger distances, and how people might be enabled to continue their social engagements with families and groups who live elsewhere.

In studying families as networks, two dominant questions emerge: How do families constitute themselves as unified, culturally specific networks through the circulation of knowledge and resources? And how should ethnographers conceive of the nodes - people,${ }^{10}$ houses, community centers, churches, and so on - through which objects and knowledge flow? For scholars of Pacific diaspora, these questions have largely been addressed through a dual focus: First, they examine how Pacific exchange systems alter as the distances goods and people must traverse become greater. This concern is often conveyed as queries surrounding the ways people express and claim cultural identity, an identity that is frequently discussed by people on the ground as being synonymous with participation in fashioning durable exchange relations across distances (see Linnekin and Poyer I990; Macpherson 1997; Lee 2004a, 2004b). Second, as they have become increasingly cognizant of the reflexive stance people take toward the networks to which they belong, scholars are exploring the multivalent layers of commitment that people have, and that others perceive them to have, to these various networks.

In recent years, the concern with reflexivity has become ethically charged, as indigenous scholars and activists have increasingly pointed out that the indigenous epistemologies that ethnographers study are often implicitly undercut by the ways academics circulate knowledge (see Gegeo 200I; 
Smith I999). Much of Pacific diaspora scholarship emerges out of critiques of ethnography and of the anthropological project in general (for elegant additions to as well as overviews of these critiques, see Diaz and Kauanui 200I; Teaiwa 2005; White and Tengan 200I). These critiques raise a salient caution for ethnographers committed to tracing both how knowledge circulates within diasporas and how those who circulate the knowledge reflexively understand links to knowledge framed as cultural. Ethnographers and their interlocutors on the ground often have very different understandings of what constitutes cultural knowledge, of how one evinces this knowledge, and of how this knowledge should be circulated. For example, ethnographers often exhibit cultural knowledge in ways, such as publishing, that are contrary to their interlocutors' understanding of how it should be made available (Hereniko 2000). This difference undermines the very epistemological practices that ethnographers are studying. It is not the content that ethnographers implicitly undercut (at least, not often); rather, it is the process by which this knowledge is supposed to circulate, and to whom. Too frequently, these different relationships to cultural knowledge and cultural expertise have been accompanied by power inequalities. Other scholars of Pacific diaspora have thus wisely raised this caution to ethnographers: to be reflexively aware of the differences between anthropological knowledge and ones' interlocutors' knowledge. ${ }^{11}$

\section{DIASPORIC EXCHANGES}

When anthropologists have studied Pacific exchange relations as both locally situated and situating the local, they have often found this useful for generating critiques of Euro-American practices of exchange (Gregory I982; Mauss 1954; Strathern 1988a, I988b). Ethnographers of Pacific diaspora have also found that thinking about the exchange relations in diaspora has become a fruitful ground for understanding how families fashion experiences of scale, and various unities of scale, across distances and times. ${ }^{12}$ Given people's lived experiences, this shift in focus is unsurprising. Before migration, people have many social arenas for exploring how families can be made into unities of various sizes, and do not necessarily have to rely on ritualized moment for examining the form. After migrating, exchanges tend to be the primary arena for such explorations. ${ }^{13}$ This is partially because Pacific Islanders most often migrate into countries 
such as New Zealand, Australia, and the United States, all of which have complex histories of colonialism, past and ongoing, with Pacific nations. Infrastructures in these countries encourage living as nuclear families rather than as extended ones. ${ }^{14}$ Ritual exchanges, as well as the preparations for these exchanges, become a primary arena through which people can reveal their families as cohesive unities, often concealing fissures at the same time. These exchanges are moments in which participants are reflexively concerned with representing their extended families as both unified and strong in multiple communities - local and transnational. ${ }^{15}$

To describe in detail how ritual exchanges can be viewed as arenas for exploring how families represent themselves as unified networks, I turn to accounts of Tongan exchange networks in migration. Many ethnographers have recently discussed the ways in which Tongans exchange across distance. ${ }^{16}$ In this section, I read together the work of Mike Evans (200I) and Cathy Small (I997) to trace the ways exchanges historically performed largely in villages by Tongan commoners are transformed during widespread migration. As Tongans alter these exchanges in response to the exigencies of migration, exchanges become vehicles for commenting on scale and group unities. Evans's and Small's ethnographies were both written in the same historical moment, a moment when the Tongan monarchy was not yet an institution provoking debate in Tonga as well as in diasporic Tongan communities.

Evans traced three different kinds of public ritual exchanges on $\mathrm{Ha}$ 'ano Island, distinguishing between exchanges on the basis of the different kinds of unities each engenders. He classified these ritual events as civic events involving the government or nobility, church events, and individuals' life events. He wrote: "Within each of the three types of ceremonies, people act in particular ways and construct the social groups involved in slightly different ways, but within each type, people generate social groups of varying longevity and boundary strength by activating overlapping social ties to a particular individual or group of individuals located at the centre of the ceremony" (Evans 200I, I27-I28). Each type of ritual requires that people engage with unities in ways that are structured by the types of exchange - unities that Small's ethnography reveals are achieved differently outside of Tonga.

Evans described how civic ceremonies provide an arena for making visible the ties between a government representative, a noble or the king, and the people that are collectively represented. These are ceremonies that 
enable people to explore what it means to present unity as iconic-through the link made visible in exchanges between a group and a person who embodies that group at different levels of scale, from village to nation. In these moments, the act of representing a unity constitutes the social group and affirms that it is unified. For example, Evans pointed out that villages are often evoked in civic ceremonies. The village as a unit is juxtaposed with the king or the visiting nobleperson. These are moments when the unities required by the nation-state (that is, villages) are the relations that these civic exchanges activate and make visible (Evans 200I, I30). The ritual itself centers around a feast, which in Tongan contexts always entails forming two unities- the people who offer the feast and the people who receive it. Those who offer the feast become a unity through producing and contributing the food and durable wealth. Those who receive the feast become a unity by eating the food and proffering speeches honoring the feast givers. In particular, making speeches provides opportunities for exploring how a single speaker can represent social unities. The hosts and the guests each have spokespersons for the group as a whole, who give speeches that praise and reaffirm the displays of group unity made visible in the feast.

In diaspora, as Small has illustrated, civic ceremonies associated with visiting Tongan royalty provides venues for people to explore, in anticipation of the ritual feast, how to realign their multiple connections to families and churches into an expression of Tonganness. She described this process in the following passage:

In the summer of I996, when I was in San Mateo, Tongans were busily preparing for the visit of the King of Tonga to the area. It was the talk of the weekend, of the year-what each church would do; who would perform at the dances; what the relatives, and relatives of relatives, of the royal family were preparing. The King would see, people said, a turnout and a display of goods that was beyond all he had seen before. There is substantial money expended at these events, including donations to the clergy and monetary gifts to the nobility. As Manu put it: "We do everything here the same as in the islands. Only here, it's more and it's better." (Small I997, 7I)

Those involved were quite conscious that they were Tongans overseas, and that the purpose of the exchange was to reveal to the king the strength and resources that they as Tongans had amassed in the United States. In the exchange, they were implicitly competing with what Tongans in Tonga 
can offer-exhibiting their relative success. In addition, they were displaying their continuing allegiance to Tonganness. In diaspora, at the time of Small's study, demonstrating one's commitment to Tonga as represented by the king took on different connotations than a similar demonstration in Tonga.

Notice also in Small's account what has been reconfigured from civic ceremonies in Tonga as described by Evans. Instead of villages functioning as the social unit, churches have become the salient arenas through which to organize exchanges in anticipation of the king's visit. As Evans pointed out, villages in Tonga are not often the unit for constructing exchanges (see also Marcus I993, 28-29); these are units linked primarily to efforts to connect Tongans to the nation-state. The substitution of church for village thus transforms churches in the diaspora into a more central locus for imagining connections to the Tongan nation. ${ }^{17}$

If civic ceremonies provide occasions in which Tongans can explore the ways in which a person can stand for a social unity, then life-transition ceremonies offer the inverse. These are celebrations that unpack the social relations condensed in a person. Evans wrote that "within the event an individual's social ties are arranged into patterns in both formal and informal ways" (200I, I33). What relatives bring to these events, and what they take away, is largely defined by their relationship to the person being celebrated. Kin from the father's side are high ranking relative to kin from the mother's side, and, where Evans worked, tend to provide food in exchange for the mother's side's textile wealth. The exchanged objects index the complex relationships that make the person a social being. As Evans explained: "Ceremonies like first birthdays and funerals turn the vast array of potential social relationships encoded in a person's or persons' kinship relationships into actual linkages traced and traceable (by Tongans themselves) through the flow of material wealth" (200I, I34).

In diaspora, celebrating these life-cycle events has become, as I mentioned earlier, a primary way for families to sustain their connections across distances and across time. Such a celebration also provides an arena through which families begin to fashion a status that is "translocal" (comparing one local focus with another across distance) through exchanges in their local Tongan communities. Small stated: "As some Tongans point out, events can take on a competitive flair, with different families attempting to outdo others. The result is that commoner weddings in the United States can come to resemble a chiefly wedding in Tonga in terms of the 
numbers in attendance, the lavishness of the food, and the display of mats and tapa cloth" (I997, 7I). Unlike civic ceremonies, the main comparison is not between exchange within Tonga and exchange outside of Tonga. Instead, the competitive celebrations enable families to imagine themselves as interwoven unities that interact and compete across their local neighborhoods and cities. In diaspora, families' reputations must be fashioned and maintained in many different contexts-in nearby Tongan communities as well as those farther away. Constituting local family networks through these ceremonies transforms Tongan expressions of allegiance to family and tradition. The competitiveness that has always been part of these rituals becomes central, as participants use these arenas to reveal local family strengths made concrete through exchange. While transplanted civic ceremonies continue to be arenas through which Tongans explore being part of a nation-state (albeit from a distance), life-cycle events become the venue for constructing family networks in new locales. People begin developing their exchange relations translocally instead of transnationally (see also Vasta 2004, 208). Dieter Haller has criticized other diasporic scholarship that neglects this translocal aspect in favor of a transnational emphasis (2005). In turning to families as their beginning point, Pacific ethnographers have made this third focus of Pacific diaspora studies - the ties between translocal communities - a touchstone for analysis (see Macpherson 2004).

While civic ceremonies become transnational and life cycles become translocal in the Tongan diaspora, a third form of exchange rituals - church ceremonies - provides arenas for transfiguring the local into the translocal and transnational. Evans argued that church ceremonies reconfigure the participants in a feast in two important ways. First, rather than explore the ways a person can stand for a social unity, the feast celebrates a group's connection to an intangible being: the feast givers reveal through exchange their commitment to God. At the same time these church feasts center around connecting God's blessings to a person, typically a child: "Feasts motivated by the Church calendar are given to God, but also for some member or members of the feast-giving group. This is usually, but not always, a child. Both feasting activity focused on life crisis events, and those described here that arise in association with the Churches, have at their centre some individual or individuals" (Evans 200I, I39, italics in original). Through these exchanges, the feasts triangulate relationships between a family, a child, and God. The family asks for God's blessing 
so that the child can become successful, with success being measured by educational and financial achievements. The families try to structure a particular future through exchange relationships - a future that, Evans pointed out, often entails entering successfully into translocal and transnational networks. In addition, Evans stressed that through these feasts the family attempts to link the child into future obligations to their family. This strategy is important because of the risk that, when sent off to be educated or to earn money, the child may not later honor familial obligations. These feasts begin the exchange relationships that families hope will be maintained as the child grows into someone with access to resources in his or her own right. Evans observed: "From within the family, the relationship which starts with the social and economic activity focused on children, is reversed (that is, reciprocated) as children in turn focus their social and economic goals to the benefit of their parents" (200I, I48). In short, these church feasts are also efforts to ensure that the local (the child) turns into the translocal (the educated and employed, as well as the remitting migrant).

Church ceremonies in Tonga are thus hopeful events anticipating translocality (see Miyazaki 2004), while outside Tonga, they help to create both new translocal communities as well as new experiences of Tonganness. As I noted earlier, for Tongans as well as for many other Pacific diasporic communities, churches become significant sites for constituting overseas migrant communities. The services, dances, and other church activities involving exchanges are arenas through which people from different villages and islands in Tonga-people who might otherwise never have interacted so regularly-begin to enter into complex friendships and exchange relationships (see Loomis I 990 for a comparable Cook Island example). In doing so, being an "overseas Tongan" (someone who identifies as Tongan regardless of birthplace but does not live in Tonga) often becomes more salient for framing relationships-relationships that previously might have been constructed in terms of families or islands. At the same time that translocal Tongan communities are configured with churches at their center, a transnational identity-overseas Tongan - is also becoming more relevant.

The Tongan diaspora reveals how scholarship on Pacific exchanges might shed light on families' varied engagements with scale-making projects in diaspora. By viewing families as networks, scholars can interpret remittances and ritual exchanges as one of many ways to fashion unities 
at different levels of scale. This also offers a way to address culturally specific ways of constructing unities and of connecting people to places (see Marshall 2004; Ka'ili 2005). Cultural differences often emerge in these moments, in part because not all techniques for producing scale are equally effective or mutually compatible. Sometimes these diverse scale-making projects resonate with each other for a time, creating productive yet finite collaborations. In general, these scale-making projects are culturally specific, and it is this specificity that structures both how well the projects travel, and how well they articulate with other scale-making enterprises.

\section{DiASPORIC KNOWLEDGES}

I turn now to the Samoan diaspora to examine how family networks constitute themselves through the ways in which knowledge travels. In Pacific Island diaspora literature, questions of identity often also involve questions of how knowledge circulates, and how these patterns of circulation might have changed across distances. ${ }^{18}$ In this section, I argue that when people on the ground are reflecting openly about their identity, they are also expressing how they personally experience and respond to the ways knowledge circulation connects them to various communities. When a Samoan woman talks about how she no longer participates in Samoan community functions in Seattle because of the gossip she encounters (McGrath 2002, 3IO-3II), she is reflecting on how she manages the circulation of knowledge about her and through her. When a New Zealand-raised Samoan woman insists that she is Samoan despite the fact that she does not speak Samoan fluently (Anae 200I), she is commenting on more than identity labels and their efficacies; she is also addressing the ways patterns of language acquisition, such as those Elinor Ochs delineated (I988), have shifted as people move away from Sāmoa. In short, just as exchange in diaspora becomes a vehicle for addressing scale-making, so too identity becomes a vehicle for reflecting on changing patterns of knowledge circulation. ${ }^{19}$

Scholars of Pacific Island diaspora have discussed three ways in which Pacific Islanders use identity to comment on how they are involved in knowledge circulation. First, ethnographers have addressed how patterns of knowledge acquisition have impacted people's claims and understandings of identity. Second, they have examined the ways people respond to the fact that being in a community is also about knowing and being 
known by others-knowledges that can often come with high prices. Last, in Pacific diasporic studies, scholars have refigured what is often construed as knowledge loss as strategic ignorance, asking when and how it is better to actively not know. I now turn to research on the Samoan diaspora for examples of all three ways in which Pacific Island migrants use identity as a frame for reflecting on how knowledge circulates.

Scholars of Pacific Island diaspora have been inspired by Jocelyn Linnekin and Lin Poyer's suggestions that Pacific Islanders frame their identity based on context rather than heredity (Linnekin and Poyer I990; see also McGrath 2002; Spickard 2002; Tiatia I998; Tupuola 2004). These authors have pointed out that different contexts require that people express different relationships to cultural knowledge. Anne-Marie Tupuola in particular has discussed how, in order to navigate social interactions successfully, the structuring of identity in different contexts requires a wide range of skills that do not always overlap (2004). Operating as a Samoan in a welfare office is a somewhat different challenge than operating as a Samoan in a Samoan church. And, as Melani Anae pointed out (200I, 2002), the paths by which people can acquire these skills have been shifting in diaspora. As a consequence, what it means to have an identity-that is, the types of knowledges one must exhibit in order to claim an identity effectively-are also constantly changing.

Language skills in particular become a locus through which people explore this tension. Anae has suggested that in diaspora, migrants are constantly struggling to answer the question, To what degree can someone who does not speak Samoan be a Samoan? She pointed out that New Zealand-raised Samoans often have uneasy relationships with their Samoan identity, largely because of their varying degrees of comfort with the Samoan language: "Inability to speak Samoan, or tautala fa'asamoa, became the prime source of Samoan identity confusion" (Anae 200I, I IO). She continued by arguing that although her interlocutors might not be able to speak Samoan fluently, or at all, they were quite capable of understanding Samoan - that is, they were fluent listeners, not speakers. This distinction is not at all surprising, given Ochs's account of how children in Samoan villages learn languages (1988). Reading Anae and Ochs together highlights how speakers of Samoan learn their varying linguistic skills in ways no longer easily accessible in urban Auckland.

When Ochs traced how language acquisition occurs in Samoan villages, she noticed that children learn much of their information from their age- 
mates. Ochs described how child-care responsibilities are often distributed among a wide range of caregivers, but placed heavily on older siblings. Adults will monitor children's play, but from a distance: "When the infant is several months old, he or she is left for periods of time with one or more siblings. These older siblings may bring their charges with them to other activities in the village, for example to watch a game or to visit with friends. At four or five in the afternoon, the village is dotted with groups of children holding their younger sibs on their laps or straddled on their hips" (Ochs I988, 80). A great deal of children's interaction, and hence knowledge transmission, takes place between age-mates and siblings. Ochs detailed how parents and other adults often address children through commands; children are not expected to respond, simply to obey. As a consequence, children develop most of their speaking skills through play with their age-mates or slightly older relatives. But in diaspora, agemates may not speak to each other in Samoan, so the Samoan skills that New Zealand-raised migrants develop are honed through relations with parents and experiences in church: listening skills. Anae observed that these listening skills are often not taken as signs of Samoan identity by migrant Samoan communities. In general, linguistic ability becomes a controversial signpost for the degree to which various people are connected to the very practices that enable them to circulate knowledge in diaspora.

Linguistic ability or inability is often portrayed as one of many passive markers of people's abilities to participate in circulating knowledge. When the passivity is foregrounded, people's participation in various communities is discussed by both scholars and Pacific Island migrants as falling along an axis of acceptance or rejection. As apt examples, Jemaima Tiatia and Anae have both explored how being raised outside of their homelands is a contradictory experience for Pacific Islanders. ${ }^{20}$ And beyond Pacific Island diasporic communities, migrants confront complex formations of racism (Omi and Winant I994; Shankman 1993; Spoonley 200I), and are defined by others as Pacific Islanders in broad generalizations. Within Pacific diasporic communities, these Pacific Islanders receive quite mixed signals as to whether they are indeed part of the overseas Pacific community. They report being called to task for their level of linguistic skill, their dress sense, and their comportment on ritual occasions. Anae discussed this tension over identity as a journey: "The journey begins when one's Samoan identity is challenged by island-born members of one's aiga (family; extended family) or church community, and when one's identity as a 
New Zealander is challenged by Papalagi” (200I, I06). Second-generation migrants are considered Samoan by those outside of Samoan migrant communities, and considered not Samoan enough from the perspective of those constituting Samoan communities. In focusing on moments in which their identity is a dilemma, Pacific Island migrants, along with their ethnographers, are emphasizing the moments in which one can participate in circulating knowledge, or not. These are encounters in which people draw the boundaries of participation, and they draw the boundaries in ways that are then reflexively understood to be about identity claims. Refusing to allow someone to participate implies refusing to recognize someone publicly as being properly Samoan. For the most part, people engage in far more fluid and ambivalent ways when people move knowledge through and about people.

When turning to questions of identity, scholars are asking about the reflexivity needed to participate in multiple long-distance networks. The varying ways people discuss their identity point to their conscious alignment and frequent realignment of family networks that circulate knowledge and resources. Barbara Burns McGrath detailed her interlocutors' arguments for a diversity of ways to be Samoan in Seattle: "Sela said that when she first arrived, she went to church with her aunt. Everyone was very friendly and wanted her to join all sorts of groups and get involved in all the activities. She knew she made them angry by not returning but said, 'I don't want to get too close to the people. All they do is talk, talk, talk. If I go somewhere, before I get home, my auntie knows. Someone has called her.' Lack of privacy wasn't the only problem. 'The people are good, but some are lazy and they always are asking for something. I can't afford to help. I am here for my children, and everything I make I am sending home" (McGrath 2002, 3 IO-3 I I). Sela and the others McGrath interviewed used the categories of identity with an unsettled and implicitly essentializing undertone to frame what was in practice their quite varied participation in family networks. The very question these interlocutors implicitly posed-must Tonganness or Samoanness be both claimed and practiced?-is a question created by a family network's reconfiguring. As knowledge begins to flow along new paths and across greater distances, people begin to reflect on these changes. When people discuss their identity, they are also commenting on how family networks have changed; identity is a useful category for reflecting on these reconfigurations (see Marshall 2005). Thus, despite the claims of these interviewees to the con- 
trary, identity is not an achievement or an inherent quality; it is a signpost for the ways in which families are constituting diasporas, and occasionally for their failures to do so.

To define relationships to cultural knowledge only in terms of people's identity can obscure some of the intricate practices of Pacific sociality in diaspora. Many scholars have commented that one has to exist on a continuum of kinship to be a person with whom others in the Pacific can engage intelligibly and for an extended period. Tévita $\mathrm{O}$ Ka'ili detailed how this process occurred throughout his fieldwork in Hawai'i, when the Tongans he met tried to locate him spatially and genealogically (2005)..21 Tellingly, Ka'ili described how every successful mapping was accompanied by exchange; knowing about relatedness was invariably accompanied by making the relationship material, and thus substantive, through exchange. In this sense, Pacific relationships are always accompanied by consequences. Terence Loomis described some of the pressures this creates for Cook Island migrants: "When migrants move to New Zealand and begin to organize, such identities become detached from their customary residential criteria and social context. Most Pacific migrants do not live near one another on the basis of place or origin, so island or village communities are rarely reconstituted as neighbourhood units.... As the number of migrants has increased, so has the potential for competing claims for a person's participation" (I990, I80-I8I). As people change their ways of constructing the local change, so too do they change the ways they can make competing claims on each other, based on what is local. Thus, in practice, the expansiveness and fluid encompassment that many scholars of the Pacific have noted as lying at the heart of Pacific sociality must also be accompanied by strategies for disentangling as well as entangling (Shankman 1993, I68-169).

Techniques for disentangling are often implicit and contextual. Strategic ignorance in particular often remains implicit in social contexts; to be explicit about ignorance is often to undercut its strategic value. Not knowing when a relative will be visiting, or refusing to answer the phone at 6 a.m. (when it is most likely an overseas call requesting money) - these and many other "not knowings" are techniques for obliquely reducing the claims people can make on each other (Gershon 2000). While ignorance is normally portrayed by scholars in terms of cultural loss, there is a more nuanced possibility-that judicious knowing and not knowing are strategies for navigating the many claims that people can make on each other. 
Not to know the "proper" way to behave is not always an instance of cultural loss; sometimes it is a practical way to respond to claims on ones' resources.

To think about certain ignorances as strategic or productive is to move away from analyzing diasporic families in terms of cultural gains and cultural losses. Instead, the focus shifts to the ways people are engaging reflexively and recursively with the multiple social orders they encounter in their daily lives. The nature of these social orders changes from context to context, and part of the social effort is also, always, to determine what the context is - Samoan, US capitalist, US bureaucratic, and so on. In these moments, identity claims become signposts for how people are trying to frame the context as well as how they are engaging with cultural knowledge and the ways this knowledge circulates. Analytical discussions about how to be Tongan or Samoan are important largely for the epistemological insights they can provide into what is cultural knowledge and who defines it from a Tongan or Samoan perspective.

In discussing how Pacific Islanders circulate knowledge in diasporic contexts, I have tried to avoid engaging with particular dichotomies - authentic/inauthentic and cultural retention/cultural loss. These binaries steer analyses toward focusing on how diasporas might disrupt families, rather than how families might alter the ways in which they circulate knowledge and, in the process, reshape their diaspora. The changes families craft are often meant to resolve paradoxes that patterns of social organization invite when stretched across distances.

\section{Conclusion}

In general, ethnographers of Pacific diasporas examine how families shape diasporas (instead of asking questions based on the presupposition that diasporas shape families). This focus on families as the lens for thinking about diasporas can provide a rigorous basis for determining how differences are made cultural. In Pacific ethnographies, families are widely understood to be networks of people who circulate knowledge and resources according to culturally specific principles that commonly enacted (and, occasionally, heatedly debated) within the networks themselves. These families are engaged in scale-making projects that ensure that social unities are fashioned and intertwined through these different circulations. People have divergent techniques for creating scales, techniques that produce different 
sorts of transnationalisms as well as localisms. Up until the present, scholars of Pacific diasporas have primarily focused on families' scale-making projects, leaving open the question of how family unities coincide with other unities in diaspora, such as government-sponsored unities. ${ }^{22}$

Focusing on families often elides another equally vital aspect of migrant experiences-the ways government classifications and bureaucracies often encourage homogenous identities. Families are rarely the main actors contributing to how social groups are fashioned at a national scale. Instead, a government's historical relationships with dominant minorities are often the most relevant for understanding a national ethnoscape. The interactions between governments and minorities invariably define minority groups according to principles other than family practices, principles such as race or class. In these interactions, stressing one's identity as a Pacific Islander may be more advantageous politically than identifying as a member of any one group, as a result of a charged dialogue among bureaucrats, physicians, teachers, and others. Helen Morton (Lee), among others, has noted that for some, being a Pacific Islander in Australia is becoming a more salient identity than being Tongan or Samoan (2002, I46-I48). Focusing on the family does not allow one to address easily how certain identities emerge out of relationships with dominant groups and major minorities in a given ethnoscape.

Ethnographies of Pacific kinship and exchange practices have much to offer Pacific diaspora studies. In particular, the scholarly focus on families offers a useful set of strategies for analyzing how diasporas can be culturally specific circulations. Tongans construct and extend diasporas according to principles of social organization that differ from those of Samoans or Cook Islanders, for example. By suggesting that diaspora studies should become studies of diasporas, I am recommending analytical tools that privilege the differences emerging when people circulate knowledge and objects. For scholars, family members become nodes in a culturally specific network, that is, conduits for distributing knowledge and resources. Thus, both knowledge and resources move through and between people in more or less predictable ways, a predictability that allows families to emerge as cohesive and culturally specific networks. It is through this specificity that families fashion diasporas that are culturally different, with different longevities and paradoxes. 
I want TO THANK Cluny Macpherson and Melissa Demian for their timely intellectual interventions as well as Mac Marshall, Michael D Lieber, and four anonymous reviewers for their inspiring editorial comments.

\section{Notes}

I See Kaeppler I978; Dureau I998. For some of the first scholarly discussions directly addressing Pacific diasporas, see Lieber I977; Macpherson, Shore, and Franco I978; and Pitt and Macpherson I974.

2 For alternative accounts of Pacific diasporas, see Chappell I999; Clifford 200I; Diaz 2004; Kauanui 2007; Kelly 1995; Stillman 2005; and Thaman 1985. Appadurai defined ethnoscapes as "the landscapes of group identity" (I 996, 48). When discussing ethnoscapes, scholars are addressing the histories of how different ethnic groups arrived and interacted with each other at a given location. For the purposes of this overview, it is as important that governments help structure how different social groups interact with each other, often creating ethnic hierarchies. See Williams I989 for a more detailed discussion of nations and ethnic hierarchies; see Kauanui 2007 for a discussion of how Hawaiians have been affected by the structures of the ethnoscapes they encounter in diaspora.

3 See Diaz and Kauanui 200I; Diaz 2004; Macpherson 200I; Stillman 2004; Teaiwa 2005 .

4 Most ethnographies focus on Samoan and Tongan migration, with some work on Palauan and other Micronesian migrants. For some perspectives on diaspora with a Micronesian slant, see Asang 2000; Grieco 2003; and Marshall 2004.

5 The abbreviation mirab refers to MIgration, Remittances, Aid, and Bureaucracy (see Bertram and Watters I985). Marshall Islanders provide the exception to the usual direction of money flows between migrants and those at home. In this unusual case, the flow of money is reversed, traveling from the Marshall Islands to the migrants in Hawai'i and California (Hess, Nero, and Burton 200I).

6 Gailey suggested that the inability of the Tongan state to accurately assess or tax the flow of remittances into the country is a sign of how weak the state is (I992, 6I).

7 See Alexeyeff 2004 for a similar approach to Cook Islands diasporic exchanges. Alexeyeff turned to food instead of textiles, but also traced how objects made in the Cook Islands can have a symbolic value that undercuts remittance analysts' assumption that only money received can adequately compensate for money given.

8 Note that this makes intercultural marriage indicative of far more than a two-person alliance. 
9 Here I am using networks in ways compatible with actor-network theorists' usage (see Latour I999; Law I999).

Io For a complex discussion of people as nodes, see Young Leslie 2004.

I I See Diaz and Kauanui 200I; Gegeo 200I; Hereniko 2000; Smith I999; Teaiwa 2005; White and Tengan 200I.

I 2 In discussing scale and scale-making projects, I am relying on Anna Tsing's description of scale-making. She defined scale and scale-making in the following manner:

Scale is the spatial dimensionality necessary for a particular kind of view, whether up close or from a distance, microscopic or planetary. I argue that scale is not just a neutral frame for viewing the world; scale must be brought into being: proposed, practiced, and evaded, as well as taken for granted. Scales are claimed and contested in cultural and political projects. A "globalism" is a commitment to the global, and there are multiple, overlapping, and somewhat contradictory globalisms; a "regionalism" is a commitment to the region; and so on. Not all claims and commitments are particularly effective. Links among varied scale-making projects can bring each project vitality and power. $(2005$, 58)

I3 I want to thank Toeutu Faaleava for this insight.

I4 See Franco and Aga 1997; Gailey 1997; Gershon 2001; Macpherson 1997. However, as Cluny Macpherson pointed out to me (pers comm, 2006), Pacific Island migrants persisted in living in extended family networks, with "nuclear" households serving as nodes.

I 5 See Besnier 2004; Cowling 2002; Evans 200I; Small I997; James I997; Addo 2004; Lee 2003.

I6 This focus on ritual exchange in Pacific diaspora literature may partially be a consequence of the communities studied. Much of the literature discusses Samoan and Tongan migrants-Pacific Island groups who are particularly known for their commitments to large ritual exchanges that rely on family relations ranging from Australia to Alaska.

I7 This transformation also occurs in Samoan communities; see Janes I990; Macpherson and Macpherson 200I; and Va'a 200I. Loomis argued that this is an ideal rather than a reality for Cook Island migrants in New Zealand (I990, I70).

I 8 See Anae 200I; Diaz and Kauanui 200I; Duranti 1997; Kauanui I998; Small 1997; Teaiwa 2001, 2005, 2006; Tuimaleali'ifano 1990. For discussions of how the medium affects how knowledge circulates in the Pacific diaspora, see Franklin 2003, 2004; Hammond I988; and Howard I999.

I9 I have been emphasizing knowledge circulation as central, but this circulation should not be taken for granted. Knowledge does not always circulate; families are filled with secrets and silences as well as disclosures. 
20 See also Fairburn-Dunlop and Makisi 2003 for first-person accounts of the contradictions one can experience in Pacific diasporas.

2I Ka'ili argued these two axes are powerfully intertwined (2005).

22 In my focus on how families constitute themselves as diasporic networks, I am eliding an important aspect of how Pacific Island migrants experience diaspora. Migrants are not only configuring and reconfiguring family networks to encompass distances, they are also moving into contexts in which the boundaries between families and other entities, such as communities or governments, are constituted in new ways. Pacific Islanders experience the division between families and governments as the complex legacies of colonial and postcolonial attempts to fashion populations into a citizenry. To begin with such a focus on citizenship is to presuppose a division between governments and families that was not familiar to Pacific Islanders prior to colonization, one that requires people to see as distinct what they must work quite hard to separate. In fact, these debates point to the considerable amount of energy modern nation-states devote to maintaining the constantly shifting boundaries between the state and the family. Much of this energy is required because the intersection between governments and family is not a given but must be actively constructed.

\section{References}

Addo, Ping-Ann

2004 Kinship Cloth and Community in Auckland, New Zealand: Commoner Tongan Women Navigate Transnational Identity Using Traditionally Styled Textile Wealth. PhD dissertation, Yale University.

Alexeyeff, Kalissa

2004 Love Food: Exchange and Sustenance in the Cook Islands Diaspora. Australian Journal of Anthropology I 5:68-80.

Anae, Melani

200I The New "Vikings of the Sunrise": New Zealand-Borns in the Information Age. In Tangata O Te Moana Nui: Evolving Identities of Pacific Peoples in Aotearoa/New Zealand, edited by Cluny Macpherson, Paul Spoonley, and Melani Anae, Ior-I2 I. Palmerston North, NZ: Dunmore Press.

2002 Papalagi Re-Defined: Toward a New Zealand-Born Samoan Identity. In Spickard, Rondilla, and Wright 2002, I 50-I69.

Appadurai, Arjun

I986 Theory in Anthropology: Center and Periphery. Comparative Studies in Society and History 28 (2): 356-36I.

I996 Modernity at Large: Cultural Dimensions of Globalization. Minneapolis: University of Minnesota Press. 
Asang, Isebong

2000 Remaking Footprints: Palauan Migrants in Hawai'i. The Contemporary Pacific I 2:37 I-384.

Bertram, I G, and R F Watters

I985 The mirab economy in the South Pacific Microstates. Pacific Viewpoint 27:496-520.

Besnier, Niko

2004 Consumption and Cosmopolitanism: Practicing Modernity at the Second-Hand Marketplace in Nuku'alofa, Tonga. Anthropological Quarterly $77: 7-45$.

Brettell, Caroline

2003 Anthropology and Migration. Walnut Creek, CA: Altamira Press.

Brown, Richard

I995 Hidden Foreign Exchange Flows: Estimating Unofficial Remittances to Tonga and Western Samoa. Asian and Pacific Migration Journal 4 (I): 35-54.

Chappell, David A

I999 Transnationalism in Central Oceanian Politics: A Dialectic Of Diasporas And Nationhood? Journal of the Polynesian Society 108:277-303.

Clifford, James

200I Indigenous Articulations. The Contemporary Pacific I3:468-490.

Connell, John, and Richard P C Brown

I995 Migration and Remittances in the South Pacific: Towards New Perspectives. Asian and Pacific Migration Journal 4 (I): I-33.

Cowling, Wendy

2002 Motivations for Contemporary Tongan Migration. In Spickard, Rondilla, and Wright 2002, 99-II7.

Diaz, Vicente $\mathrm{M}$

2004 To "P" or Not to "P"? Marking the Territory Between Pacific Islander and Asian American Studies. Journal of Asian-American Studies 7 (3): I $83-208$.

Diaz, Vicente M, and J Kēhaulani Kauanui, editors

200I Native Pacific Cultural Studies on the Edge. Special issue of The Contemporary Pacific I 3 (2).

Duranti, Alessandro

I997 Indexical Speech across Samoan Communities. American Anthropologist 99:342-354.

Dureau, Christine

I998 Decreed Affinities: Nationhood and the Western Solomon Islands. Journal of Pacific History 33 (2):197-220.

Epstein, Arnold Leonard

I969 The Network and Urban Social Organization. In Social Networks in 
Urban Situations, edited by J Clyde Mitchell, 77-I I6. Manchester, UK: Manchester University Press.

Evans, Mike

200I Persistence of the Gift: Tongan Tradition in Transnational Context. Waterloo, on: Wilfrid Laurier University Press.

Fairbairn-Dunlop, Peggy, and Gabrielle Makisi

2003 Making Our Place: Growing up PI in New Zealand. Palmerston North, NZ: Dunmore Press.

Fardon, Richard, editor

I990 Localizing Strategies: Regional Traditions of Ethnographic Writing. Edinburgh: Scottish Academic Press.

Franco, Robert, and Simeamativa Aga

I997 From Houses without Walls to Vertical Villages: Samoan Housing Transformations. In Home in the Islands: Housing and Social Change in the Pacific, edited by Jan Rensel and Margaret Rodman, I75-I93. Honolulu: University of Hawai'i Press.

Franklin, Marianne

2003 I Define My Own Identity: Pacific Articulations of "Race" and "Culture" on the Internet. Ethnicities 3:465-490.

2004 Postcolonial Politics, the Internet and Everyday Life: Pacific Traversals Online. London: Routledge.

Gailey, Christine Ward

I992 A Good Man Is Hard to Find: Overseas Migration and the Decentered Family in the Tongan Islands. Critique of Anthropology I 2 (I):47-74.

Gegeo, David Welchman

200I Cultural Rupture and Indigeneity: The Challenge of (Re)Visioning "Place" in the Pacific. The Contemporary Pacific I3:49I-507.

Gershon, Ilana

2000 How to Know When Not to Know: Strategic Ignorance When Eliciting for Samoan Migrant Exchanges. Social Analysis 44:84-I05.

200I Going Nuclear: New Zealand Bureaucratic Fantasies of Samoan Extended Families. In New Directions in Anthropological Kinship, edited by Linda Stone, 303-32I. Lanham, MD: Rowman and Littlefield Publishers.

Goss, Jon, and Bruce Lindquist

2000 Placing Movers: An Overview of the Asian-Pacific Migration System.

The Contemporary Pacific I 2:38 5-4 I 4 .

Gregory, Chris A

I982 Gifts and Commodities. London: Academic Press.

Grieco, Elizabeth

2003 The Remittance Behavior of Immigrant Households: Micronesians in Hawai' $i$ and Guam. New York: LFB Scholarly Publishing. 
Hammond, Joyce

I988 Visualizing Themselves: Tongan Videography in Utah. Visual Anthropology I:379-400.

Hau'ofa, Epeli

I994 Our Sea of Islands. The Contemporary Pacific 6:I48-I6I. First published in A New Oceania: Rediscovering Our Sea of Islands, edited by Vijay Naidu, Eric Waddell, and Epeli Hau'ofa, 2-I6. Suva: School of Social and Economic Development, University of the South Pacific (I993).

I998 The Ocean in Us. The Contemporary Pacific I0:39I-4Io.

Haller, Dieter

2005 Let it Flow: Economy, Spirituality and Gender in the Sindhi Network. Anthropological Theory 5:I 54-I75.

Hereniko, Vilsoni

2000 Indigenous Knowledge and Academic Imperialism. In Remembrance of Pacific Pasts: An Invitation to Remake History, edited by Robert Borofsky, 78-9r. Honolulu: University of Hawai'i Press.

Hess, Jim, Karen L Nero, and Michael L Burton

200I Creating Options: Forming a Marshallese Community in Orange County, California. The Contemporary Pacific I3:89-I 2 I.

Howard, Alan

I999 Pacific-Based Virtual Communities: Rotuma on the World Wide Web. The Contemporary Pacific II:I60-I75.

James, Kerry

I997 Reading the Leaves: The Role of Tongan Women's Traditional Wealth and Other "Contraflows" in the Processes of Modern Migration and Remittance. Pacific Studies 20:I-29.

Janes, Craig

I990 Migration, Social Change, and Health: A Samoan Community in Urban California. Stanford: Stanford University Press.

Kaeppler, Adrienne

I978 Exchange Patterns in Goods and Spouses: Fiji, Tonga and Samoa. Mankind I I:248-25 I.

Ka'ili, Tēvita O

2005 Tauhi vā: Nurturing Tongan Sociospatial Ties in Maui and Beyond. The Contemporary Pacific I7:83-II 4 .

Kauanui, J Kēhaulani

I998 Off-Island Hawaiians "Making” Ourselves at "Home": A [Gendered] Contradiction. Women's Studies International Forum 2I (6): 68 I-693.

2007 Diasporic Deracination and "Off-Island" Hawaiians. The Contemporary Pacific I 9:13 8-I60. 
Kelly, John

I995 Diaspora and World War, Blood and Nation in Fiji and Hawai'i. Public Culture 7:475-497.

Latour, Bruno

I999 Pandora's Hope: Essays on the Reality of Science Studies. Cambridge, mA: Harvard University Press.

Law, John

I999 After ANT: Complexity, Naming and Topology. In Actor Network Theory and After, edited by John Law and John Hassard, I-I4. Oxford: Blackwell Publishers.

Lee, Helen [Morton]

2003 Tongan Overseas: Between Two Shores. Honolulu: University of Hawai'i Press.

2004a "Second Generation" Tongan Transnationalism: Hope for the Future? Asia Pacific Viewpoint 45 (2): 235-254.

2004b All Tongans Are Connected: Tongan Transnationalism. In Globalization and Culture Change in the Pacific Islands, edited by Victoria S Lockwood, I33-I48. Upper Saddle River, NJ: Prentice Hall.

Lieber, Michael D, editor

I977 Exiles and Migrants in Oceania. Honolulu: University of Hawai'i Press.

Linnekin, Jocelyn, and Lin Poyer, editors

I990 Cultural Identity and Ethnicity in the Pacific. Honolulu: University of Hawai'i Press.

Loomis, Terence

1990 Pacific Migrant Labour, Class and Racism in New Zealand: Fresh off the Boat. Aldershot, uk: Avebury Press.

Macpherson, Cluny

I992 Economic and Political Restructuring and the Sustainability of Migrant Remittances: The Case of Western Samoa. The Contemporary Pacific 4:I09-I35.

I994 Changing Patterns of Commitment to Island Homelands: A Case Study of Western Samoa. Pacific Studies I7 (3): 83-1 I6.

I997 Changing Contours of Kinship: The Impacts of Social and Economic Development on Kinship Organization in the South Pacific. Pacific Studies 22:7 I-94.

200I Pacific Islanders. Asia Pacific Viewpoint 42 (I): 27-33.

2004 Transnationalism and Transformation in Samoan Society. In Globalization and Culture Change in the Pacific Islands, edited by Victoria Lockwood, I65-I8I. Upper Saddle River, nJ: Prentice Hall. 
Macpherson, Cluny, and La'avasa Macpherson

200I Evangelical Religion among Pacific Island Migrants: New Faiths or Brief Diversions? Journal of Ritual Studies I 5:27-37.

Macpherson, Cluny, Bradd Shore, and Robert Franco

1978 New Neighbors: Islanders in Adaptation. Santa Cruz, CA: Center for Pacific Studies.

Marcus, George

I993 Tonga's Contemporary Globalizing Strategies: Trading on Sovereignty amidst International Migration. In Contemporary Pacific Societies: Studies in Development and Change, edited by Victoria S Lockwood, Thomas G Harding, and Ben J Wallace, 2 I-33. Englewood Cliffs, NJ: Prentice-Hall.

Marshall, Mac

2004 Namoluk Beyond the Reef: The Transformation of a Micronesian Community. Boulder, co: Westview Press.

Mauss, Marcel

I990 The Gift: The Form and Reason for Exchange in Archaic Societies. Translated by W D Halls. New York: W W Norton Co. Originally published in London, I954.

Mayer, Philip

I96I Townsmen or Tribesmen. Capetown: Oxford University Press.

I962 Migrancy and the Study of Africans in Town. American Anthropologist 64:576-592.

McGrath, Barbara Burns

2002 Seattle Fa'a Sämoa. The Contemporary Pacific I4:307-340.

Miyazaki, Hiro

2004 The Method of Hope: Anthropology, Philosophy, and Fijian Knowledge. Stanford: Stanford University Press.

Morton, Helen

2002 Creating Their Own Culture: Diasporic Tongans. In Globalization and Culture Change in the Pacific Islands, edited by Victoria Lockwood, I35-I49. Upper Saddle River, NJ: Prentice Hall. Originally published in The Contemporary Pacific IO:I-30 (I998).

Ochs, Elinor

I988 Culture and Language Development: Language Acquisition and Language Socialization in a Samoan Village. Cambridge: Cambridge University Press.

Omi, Michael, and Howard Winant

I994 Racial Formation in the United States: From the I960s to the I990s. Second edition. New York: Routledge. 
Park, Kye-Young

I997 The Korean American Dream: Immigrants and Small Business in New York City. Ithaca, NY: Cornell University Press.

Pauw, Berthold A

I963 The Second Generation. Cape Town: Oxford University Press.

Pitt, David C, and Cluny Macpherson

I974 Emerging Pluralism: The Samoan Migrant Community in Urban New Zealand. Auckland: Longman Paul.

Portes, Alejandro, and Rubén G Rumbaut

200I Legacies: The Story of the Immigrant Second Generation. Berkeley: University of California Press.

Shankman, Paul

I993 The Samoan Exodus. In Contemporary Pacific Societies: Studies in Development and Change, edited by Victoria Lockwood, Thomas G Harding, and Ben J Wallace, I 56-I70. Englewood Cliffs, NJ: Prentice Hall.

Small, Cathy

I995 The Birth and Growth of a Polynesian Women's Exchange Network. Oceania 65 (3): 234-256.

1997 Voyages: From Tongan Villages to American Suburbs. Ithaca, NY: Cornell University Press.

Smith, Linda Tuhiwai

I999 Decolonizing Methodologies: Research and Indigenous Peoples. Dunedin, NZ: University of Otago Press.

Spickard, Paul

2002 Pacific Islander Americans and Multiethnicity: A Vision of America's Future? In Spickard, Rondilla, and Wright 2002, 40-56.

Spickard, Paul, Joanne Rondilla, and Debbie Hippolite Wright

2002 Pacific Diasporas: Island Peoples in the United States and Across the Pacific. Honolulu: University of Hawai'i Press.

Spoonley, Paul

200I Transnational Pacific Communities: Transforming the Politics of Place and Identity. In Tangata O Te Moana Nui: The Evolving Identities of Pacific Peoples in Aotearoa/New Zealand, edited by Cluny Macpherson, Paul Spoonley, and Melani Anae, 8I-96. Palmerston North, NZ: Dunmore Press.

Stillman, Amy Ku'uleialoha

2004 Pacific-ing Asian Pacific American History. Journal of Asian-American Studies 7 (3): 24I-270.

Strathern, Marilyn

I988a Concrete Topographies. Cultural Anthropology 3:88-96.

I988b Gender of the Gift. Berkeley: University of California Press. 
I996 Cutting the Network. The Journal of the Royal Anthropological Institute 2 (3): 5 I 7-535.

Teaiwa, Teresia

200I Lo(o)sing the Edge. The Contemporary Pacific I3:343-357.

2005 Native Thoughts: A Pacific Studies Take on Cultural Studies and Diaspora. In Indigenous Diasporas and Dislocations, edited by Graham Harvey and Charles D Thompson Jr, I 5-36. Burlington, vT: Ashgate Publishing Limited.

2006 On Analogies: Rethinking the Pacific in a Global Context. The Contemporary Pacific I 8:7 I-87.

Thaman, Konai Helu

I 985 The Defining Distance: People, Places, and Worldview. In Mobility and Identity in the Island Pacific, edited by Murray Chapman. Special issue of Pacific Viewpoint 26 (I): I06-II 5.

Tiatia, Jemaima

I998 Caught Between Cultures: A New Zealand-born Pacific Island Perspective. Auckland: Christian Research Association.

Tsing, Anna

2005 Friction: An Ethnography of Global Connection. Princeton: Princeton University Press.

Tuimaleali'ifano, Morgan

I990 Samoans in Fiji. Suva: Institute of Pacific Studies.

Tupuola, Anne-Marie

2004 Pasifika Edgewalkers: Complicating the Achieved Identity Status in Youth Research. Journal of Intercultural Studies 28 (I): 87-Ioo.

Va'a, Leulu Felise

200 I Saili Matagi: Samoan Migrants in Australia. Suva: Institute of Pacific Studies.

Vasta, Ellie

2004 Community, the State and the Deserving Citizen: Pacific Islanders in Australia. Journal of Ethnic and Migration Studies 30 (I):I95-2 I3.

Vete, Mele

I995 The Determinants of Remittances among Tongans in Auckland. Asian and Pacific Migration Journal 4 (I): 55-68.

White, Geoffrey M, and Ty Kāwika Tengan

200I Disappearing Worlds: Anthropology and Cultural Studies in Hawai'i and the Pacific. The Contemporary Pacific I3:38 I-4 I 6.

Williams, Brackette

I989 A Class Act: Anthropology and the Race to Nation Across Ethnic Terrain. Annual Review of Anthropology i 8:40I-444.

Yamamoto, Matori

I997 Samoan Diaspora and Ceremonial Exchange. In Population Movement 
in the Modern World I: Contemporary Migration in Oceania; Diaspora and Network, edited by Ken'ichi Sudo and Shuji Yoshida, 65-76. JCAS Symposium Series 3. Osaka: Japan Center for Area Studies, National Museum of Ethnology.

Young Leslie, Heather

2004 Pushing Children Up: Maternal Obligation, Modernity and Medicine in the Tongan Ethnoscape. In Globalization and Culture Change in the Pacific Islands, edited by Victoria Lockwood, 390-4I3. Upper Saddle River, NJ: Prentice Hall.

\section{Abstract}

This article explores what long-standing analytical traditions in Pacific ethnographies can offer Pacific diaspora studies. In particular, I advocate researchers' reconceptualizing their unit of analysis when interrogating the relationships between families and diasporas, and argue that family networks fashion diasporas' longevity and tangibility. Emphasizing families' social organization encourages Pacific diaspora studies to focus on how and when cultural differences have effects.

KEYWORDS: diaspora, migrants, networks, knowledge circulation, exchange, families 